\title{
ALIEN PLANT SPECIES IN THE AGRICULTURAL HABITATS OF UKRAINE: DIVERSITY AND RISK ASSESSMENT
}

\author{
RAISA BURDA
}

Institute for Evolutionary Ecology, NAS of Ukraine, 37, Lebedeva Str., 03143 Kyiv, Ukraine; e-mail: riburda@ukr.net

\begin{abstract}
Burda R.: Alien plant species in the agricultural habitats of Ukraine: diversity and risk assessment. Ekológia (Bratislava), Vol. 37, No. 1, p. 24-31, 2018.

This paper is the first critical review of the diversity of the Ukrainian adventive flora, which has spread in agricultural habitats in the $21^{\text {st }}$ century. The author's annotated checklist contains the data on 740 species, subspecies and hybrids from 362 genera and 79 families of non-native weeds. The floristic comparative method was used, and the information was generalised into some categories of five characteristic features: climamorphotype (life form), time and method of introduction, level of naturalisation, and distribution into 22 classes of three habitat types according to European Nature Information System (EUNIS). Two assessments of the ecological risk of alien plants were first conducted in Ukraine according to the European methods: the risk of overcoming natural migration barriers and the risk of their impact on the environment. The exposed impact of invasive alien plants on ecosystems has a convertible character; the obtained information confirms a high level of phytobiotic contamination of agricultural habitats in Ukraine. It is necessary to implement European and national documents regarding the legislative and regulative policy on invasive alien species as one of the threats to biotic diversity.
\end{abstract}

Key words: adventive flora, taxonomiccomposition, typologicalstructure.

\section{Introduction}

The threat of alien plant species, spreading in Ukrainian agricultural habitats, is indeed real. In recent decades, there has been an intensification of the invasions of aggressive neophytes in Ukraine. A checklist of alien plant species, containing 740 species, was compiled in the endangered areas of our country. Here, alien species are considered as species that formed secondary areas. In this article, in addition to alien species, all non-native species distributed in agricultural environments regardless of man are analysed. However, only the ecological risk of alien species is assessed.

The goals of the study were to research the composition of alien species and the taxonomic and typological structure of the adventive flora and assess the ecological risk of alien plants in agricultural habitats. 


\section{Material and methods}

The checklist of alien plant species in the agricultural habitats of Ukraine is the result of authorial research since 2001 and the analysis of other scientific papers by the author. A pragmatic classification of the Angiosperm system (Mosyakin, 2013) and international databases on the nomenclature (The International Plant Name Index; ...; The Plant List. A working list of all plant species ...) were used. The typological analysis involved the application of floristic comparative methods.

The information was generalised using five descriptions of species according to the Ecoflora of Ukraine (Didukh et al., 2000): climamorphotype, 5 categories; time of introduction, 3 categories; method of introduction, 3 categories; level of naturalisation, 4 categories and distribution of species in 22 classis of three habitat types of European Nature Information System (EUNIS) (Davies et al., 2004). The habitat types are listed in accordance with the habitat classification version for Ukraine (Didukh et al., 2016). In Ukraine, 'agricultural habitats' is the term used to describe agricultural land (arable field, old field, fallow, haymaking, pasture meadow, cultivated pasture, intensive pasture and orchard) and land for non-agricultural use (rural settlement, field road, forest belt, protective forest tape). The graphic material was prepared using Statistical 6.0 package (Stat Soft. Inc.).

The risk assessment for overcoming natural migration barriers was made based on the known botanical classification of alien plant species (Richardson et al., 2000). The study of the ecological impact of alien plant species involved the use of the unified classification of the latter, depending on the magnitude of their environmental impact (Blackburn et al., 2014). The classes of impacts were distinguished as follows: 'massive', 'major', 'moderate', 'minor' and 'minimal'. The impact class was determined using mechanisms of the Global Invasive Species Database, The International Union for Conservation of Nature IUCN (Blackburn et al., 2014), such as competition, hybridisation, transmission of diseases, parasitism, toxicity, bioaccumulation, inflammability and interaction with other invasive species.

\section{Results}

The taxonomic diversity of the studied weed flora comprises 700 species, 23 subspecies and 17 hybrids from 362 genera and 79 families (about 65\% of those recorded in the country). Amongst families, Asteraceae (55 genera, 117 species), Poaceae (29 and 85, respectively) and Brassicaceae (30 and 53) are the richest in the quantity of genera and species. Consequently, there is an evident prevalence of the families, common for our flora, whose richness in adventive fractions are predefined by their variety in Palaearctic on the whole. Exotic alien species belong to the families with one ( 22 families) or two (13 families) species, for example, Martyniaceae (Proboscidea louisiana (Mill.) Thell.), Hippocastanaceae (Aesculus hippocastanum L.), Phytolaccaceae (Phytolacca americana L.), Simaroubaceae (Ailanthus altissima (Mill.) Swingle) and Commelinaceae (Commelina communis L. and Tradescantia virginiana L.). Only Amaranthaceae includes 15 species and the only genus, Amaranthus L. A separate approach for inclusion in the checklist ... is adopted for the genus Solanum. The 'List of regulated pests ... of the Ministry of Agrarian Policy of Ukraine contains Solanum rostratum Dunal. It is known from scientific publications that this quarantine weed occupied about 1,688 ha in 2002, but the measures taken allowed reducing the area to 134 ha. Three species of the genus Solanum (Solanum carolinense L., S. elaeagnifolium Cav. and S. triflorum Nutt.) in the 'List of quarantine pests...' are considered to be absent in our country. However, a rare alien species $S$. carolinense was collected in Ukraine only once: in Kyiv, near a grain mill (Mosyakin, Fedoronchuk, 1999). Another species of S. judaicum Besser was noted by Besser from Podolia in 1809, but the fate of this species is not known. As the invasion of Solanum species continues in Ukraine, all the mentioned species of the genus are included in the checklist... with the corresponding assessments. 


\section{The climamorphotype, $\%$}
s phanerophytes
a hemicryptophytes
- chamaephytes
$\checkmark$ cryptophytes

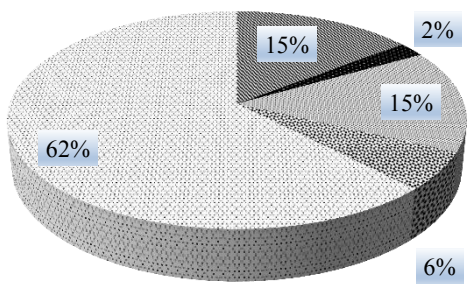

$6 \%$

$\boldsymbol{a}$

The method of introduction,

$\%$

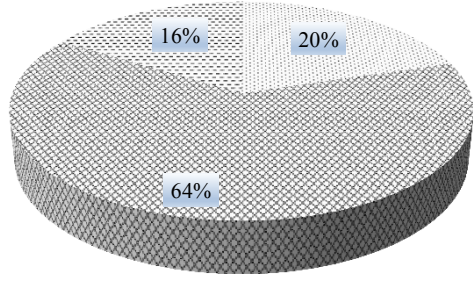

: acolutophytes $x$ ergasiophytes - xenophytes $c$

The distribution in habitats, $\%$

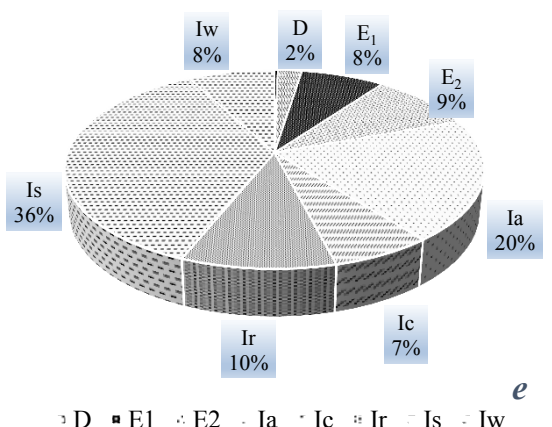

The time of introduction, $\%$

: euneophytes neophytes archaeophytes

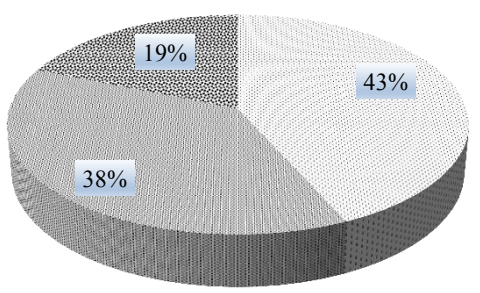

$b$

The level of naturalization, $\%$
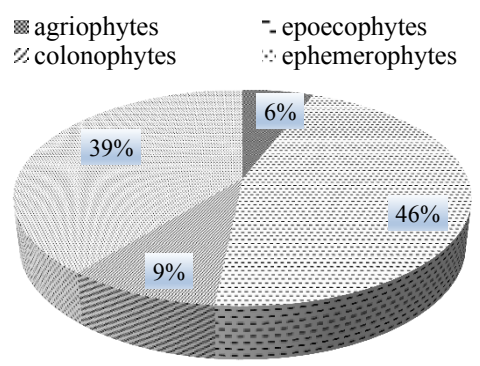

$d$

The overcome of migration barriers, $\%$

$\mathbf{x}$ "species-transformers" invasive plants

$\because$ naturalized plants

- casual alien plants

$\because$ not evaluated plants

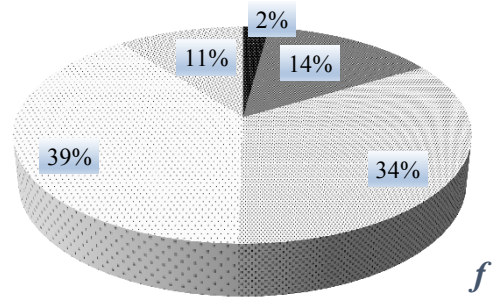

Fig. 1. Typological diversity of alien plant species in agricultural habitats.

(Marked in Fig. 1e: D, wet habitats of grass; $\mathrm{E}_{1}$, meadow steppe habitats; $\mathrm{E}_{2}$, true steppe habitats; Ia, cultivated agricultural; horticultural and domestic habitats;Ic, shrub habitats; Ir, ruderal habitats; Is, rural public habitats; and Iw, wayside habitats). 
The typological diversity of the studied weed alien species predetermines their adaptive ability, related to their existence in conditions, changed due to human activity. The non-native species are classified into five categories of climamorphotype: therophytes, cryptophytes, hemicryptophytes, chamaephytes and phanerophytes. The prevailing number of therophytes is evident, but the share of phanerophytes is also high here, which is related to the rural public habitats (Fig. 1a).

The prevailing number of neophytes and euneophytes has been observed for chronic-elements (Fig. 1b). As for the method of introduction, the ergasiophytes prevail here also (Fig. 1c). An interesting picture of variability of alien plants is seen at the level of naturalisation, which shows dynamics and instability of the studied fraction of flora. Almost half of the fraction is made up of epoecophytes, which prefer habitats disturbed by human activity. The ephemerophytes have just begun to adapt to new conditions, thus local populations have not yet formedbut are quite diverse. Some species (colonophytes) formed colonies; and only some of them - agriophytes - have their own ecological niche in semi-natural habitats (Fig. 1d).

This review of typological structure of adventive flora with high participation of unstable migration elements is a prerequisite for the accumulation of hidden environmental risks. The majority of ephemerophytes, according to the type of life strategy, are explerents that are capable of producing mass diasporas and rapidly increasing the population, occupying and retaining an additional territory.

The distribution of alien species in agricultural habitats was taken to presence-absence in three types of habitats according to EUNIS: type $D$, wet habitats of grass; type $E$, grassland habitats: grasslands, steppes and wasteland, 2 habitats; and type $I$, habitats shaped by human activity, 19 habitats. (Fig. 1e shows only habitats in which more than $2 \%$ of all the alien species are present).

In terms of overcoming migration barriers of natural character (spatial, climatic, abiotic, biotic, reproductive and the like), the alien species in agricultural habitats are presented by all five categories (Fig. 1f). The casual alien plants dominate along with the naturalised but not common species. Yet virtually invasive plants on the list are more than a hundred, and they represent an environmental risk for local plant diversity. The invasive plant category includes hard-to-eradicate weeds, for example, Amaranthus albus L., A. retroflexus L., Ambrosia artemisiifolia L., Apera spica-venti (L.) P. Beauv., Bromus squarrosus L., Centaurea diffusa Lam., Cyanussegetum Hill., Cynodon dactylon (L.) Pers., Descurainia sophia (L.) Webb ex Prantl, Diplotaxis tenuifolia (L.) DC., Echinochloa crus-galli (L.) P. Beauv., Iva xanthiifolia Nutt., Galinsoga parviflora Cav., Lactuca sativa L., L. serriola L., Setaria verticillata (L.) P. Beauv., S. viridis (L.) P. Beauv., Sinapis alba L., Sonchus arvensis L., S. asper (L.) Hill., S. oleraceus L., Tripleurospermum inodorum (L.) Sch. Bip., Rhaponticum repens (L.) Hidalgo. These include alien species of plants with a heterotrophic type of food - obligate plant parasites - such as Cuscuta campestris Yunck., C. cesatiana Bertol., C. epilinum Weihe, C. gronovii Willd. ex Roem. \& Schult., C. suaveolens Ser., C. tinei Insenga, Orobanche brassicae (Novopokr.) Novopokr., O. cernua Loefl., O. gracilis Sm., O. minor Sm. and O. ramose L. Some weeds occur exclusively in certain field habitats, for example, Monochoria korsakowii Regel \& Maack litter rice fields or Sorghum halepense (L.) Pers. is noted from time to time in the vineyards.

But the most threatening group is that of 16 'species-transformers', including Acer negundo L., Bromus tectorum (L.) Nevski, Elaeagnus angustifolia L., Grindelia squarrosa (Pursh) 
Dunal and Salix $\times$ fragilis L. They are capable of changing the nature of the ecosystem. 'A Unified Classification...' (Blackburn et al., 2014) involves the use of certain principles for assessing the response of an ecosystem to the impacts of alien plant species (Fig. 2).

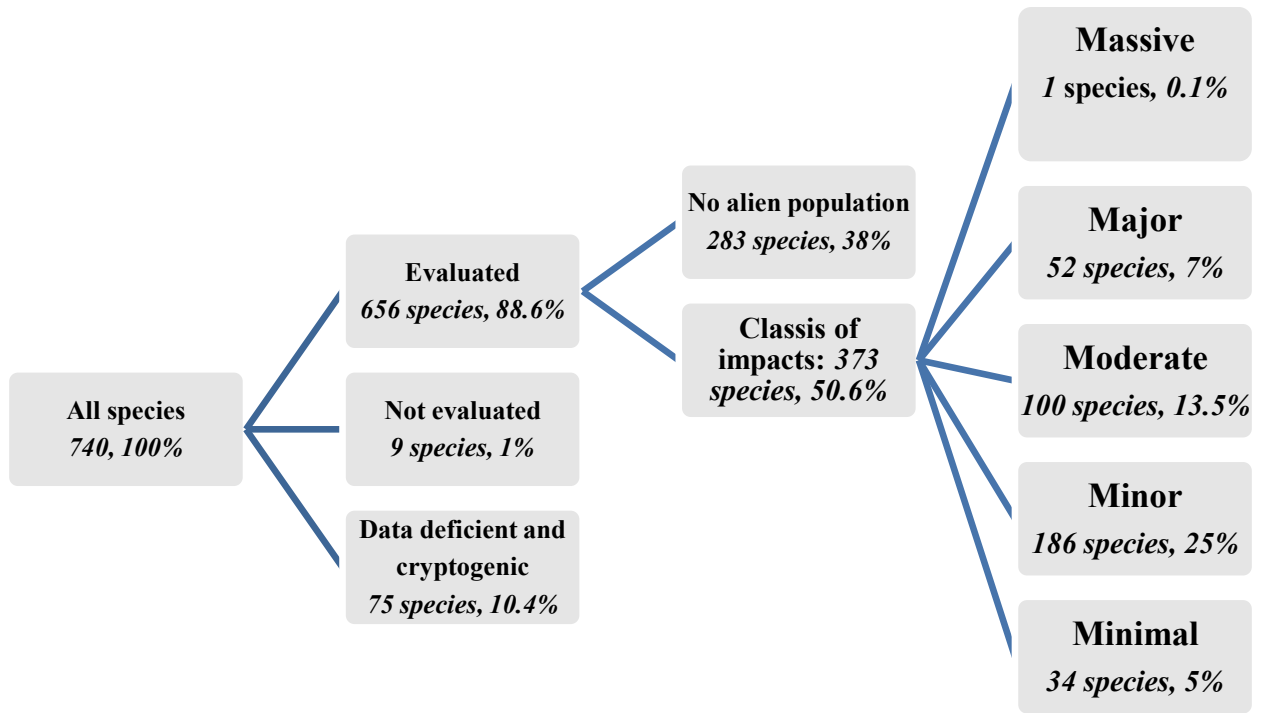

Fig. 2. Scheme of the relations between different categories of impact of alien species.

The presence of alien species of the class of greatest impacts (class of 'massive' impact) in the ecosystem has profound consequences: local extinction of native species and irreversible changes in the community composition. 'Even if the alien species is removed, the system does not recover its original state' (Blackburn et al., 2014). In our case, such an example may be found as a result of hybridisation of a native species Salix alba L. and an alien species $S$. fragilis sometimes noted in agricultural habitats.

The class of 'major' impact includes species that cause local extinction of at least one native species and lead to reversible changes in the community composition. Significant effects are caused by species recognised as 'transformers'. For example, Erigeron annuus, E. canadensis, E. strigosus var. septentrionalis and Solidago canadensis sometimes 'transform' meadow steppe habitats $\left(E_{1}\right)$. The class of 'moderate' impact includes the alien species whose appearance causes a decrease in the density of populations of local species but does not change the composition of the community. These changes are reversible, for example, Artemisia annua L., Bidens frondosa L., Conium maculatum L. and Neslia paniculata (L.) Desv. The class of 'minor' impact includes the alien species whose presence slows down the individual state, viability and growth; the renewal is impaired; the sustainability of natural species is reduced, but the density of their populations does not change. The examples include Abutilon theophrasti Medik. and Bryonia alba L. 
The alien species of the class of insignificant impacts (class of 'minimal' impact) cause minimal consequences, and it is unlikely that they have tangible impact on the environment: Anagallis arvensis subsp. $\times$ foemina (Mill.) Schinz \& Thell., Viciaervilia (L.) Willd. For a 10th part of species, there is a lack of information (deficient data and cryptogenic species): the impact of alien species that has not been demonstrated because of the inadequate study of them under new conditions. A group of the so-called 'cryptogenic species' was discovered with an indefinite status of impact on local diversity (Orobanche aegyptiaca Pers., Setaria pumila (Poir.) Roem. \& Schult., Sorghum $\times$ almum Parodi).

\section{Discussion}

On the basis of the above assessment and considering the qualitative and not quantitative characteristics, the impact of all the alien species in the studied habitats is defined as reversible, and after the removal of non-native species, the ecosystems are capable of self-revival. The exception is found in the alien species Salix fragilis, which is prone to genetic absorption of the native species $S$. alba.

The species composition of phytobiotic contamination of agricultural habitats in Ukraine coincides with the composition of alien plants in European countries. This demonstrates the European level of plant invasions. It is estimated that more than 13\% (129 out of 740 species) are on the list of 150 non-native plant species that have spread to 49 European countries (Lambdon et al., 2008). There their status is estimated as 'naturalised alien plants' or 'casual alien plants'. The highest rank on distribution is occupied by species from agricultural habitats such as Erigeron canadensis in 47 countries, Datura stramonium L. agricultural in 45 countries, Amaranthus retroflexus L. and Galinsoga parviflora Cav. in 44 countries, $\mathrm{He}$ lianthus tuberosus L. and Xanthium strumarium L. in 43 countries, Oenothera biennis and Robinia pseudoacacia in 42 countries, Galinsoga quadriradiata Ruiz \& Pav., Matricaria matricarioides, Panicum miliaceum L. and Veronica persica Poir. in 41 countries. Total in 40 or more countries there are 17 species, in 39-21 species, respectively, in 35-43 species, in 30 countries -90 species.

According to our results, the share of invading species in the local flora of the Nature Reserve Fund of the Flatland Part of Ukraine varies from 8 to 24\%; the background phytobiotic contamination is $8-10 \%$ (Burda et al., 2015). Obviously, the phytobiotic contamination of agricultural habitats is several times higher than the background ( $65 \%$ vs. $8-10 \%)$. This confirms our assumptions about the existence of a sufficiently large threat from agricultural habitats for local biotic diversity. Our results contain the applied aspect. They determine the priorities of construction of strategy for the prevention of invasive plants in the agrarian habitats.

Let us emphasise that the solution to the problem of phytobiotic pollution of agricultural habitats in our country depends not only on the application of appropriate technical measures for timely and quality carebut it also lies on the plane of Ukraine's compliance with the requirements of the Global strategy on invasive alien species (McNeely et al., 2001). The differentiation given in the paper on the classes of impacts of alien species on the environment is the basis for prioritising the national strategy on invasive alien plant species. To implement the European policy on invasive alien species, Ukraine should adopt the national strategy on 
invasive alien species, approve national and regional lists of them, introduce local codes of recommendations and so on.

\section{Conclusion}

The taxonomic richness of the adventive fraction of flora in agricultural habitats in Ukraine is 740 species from 362 genera and 79 families. The typological diversity of the fraction determines its adaptive capacity for specific habitats with regular human intervention. Amongst the climamorpho-types, the therophytes predominate and amongst the chronic-elements, the neophytes do; by the method of distribution, the ergasiophytes predominate and by the level of naturalisation, the ephemerophytes. This typological structure demonstrates the instability of the studied fraction of the flora, and a high percentage of the life strategy of the explerents in it indicates hidden environmental risks.

According to the composition of alien plants common for other European countries, phytobiotic pollution of agricultural habitats in Ukraine proves to be similar to some extent: 129 out of 740 identified weed species are mentioned amongst 150 non-native species common for 49 European countries. Unstable random species dominate or overcome natural migration barriers. There are more than a hundred of invasive species, and a group of 16 'speciestransformers' is of specific threat.

Alien species in agricultural habitats affect the environment significantly: more than onefifth of them have 'moderate' or higher classes of impacts, one-third haveclasses of 'minor' and 'minimal'impacts; about $40 \%$ have not yet created their local populations. In general, the impacts of all invasive alien species on these habitats are assessed as having a reversible character. An exception is Salix fragilis, which absorbs local S. alba sometimes.

The main reason for the intensification of expansions of invasive alien species in Ukraine in the past decades is anthropogenic. The main vectors of alien species penetration are wellknown: from a culture. The main number of species occupiedthe agricultural habitats with the intensive annual care of cereal crop fields, infertile crops fields, perennial herb fields and habitats of rural settlements. In determining the priorities for building the national strategy on invasive alien species, it is important to consider the role played by the outlined classes of environmental impacts of invasive alien species living in agricultural habitats.

The solution to the problem of phytobiotic contamination of agricultural habitats in Ukraine lies in the implementation of the European policy on invasive alien species (adoption and introduction of national and regional documents on invasive alien species of legislative and recommendatory nature).

\section{Acknowledgements}

I thank Mrs. Nelya Plakhota for helping with the editing in English.

\section{References}

Blackburn, T.M., Essl, F., Evans, T., Hulme, P.E., Jeschke, J.M., Kuhn, I., Kumschick, S., Markova, Z., Mrugała, A., Nentwig, W., Pergl, J., Pyšek, P., Rabitsch, W., Ricciardi, A., Richardson, D.M., Sendek, A., Vila, M., Wilson, 
J.R.U., Winter, M., Genovesi, P. \& Bacher S. (2014). A Unified classification of alien species based on the magnitude of their environmental impacts. PLOS Biology, 12(5), 1-11. DOI: 10.1371/journal.pbio.1001850.

Burda, R.I., Golivets, M.A. \& Petrovych O.Z. (2015). Alien species in the flora of the Nature Reserve Fund of the Flatland Part of Ukraine. Russian Journal of Biological Invasions, 6(1), 6-20. DOI: 10.1134/S2075111715010038.

Davies, C.E., Moss, D. \& Hill M.O. (2004). EUNIS habitat classification. Revised 2004. Final Report to the European Topic Centre on Nature Protection and Biodiversity. European Environment Agency.

Didukh, Ya., Plyuta, P., Protopopova, V., Ermolenko, V., Korotchenko, I., Karkutsiev, G. \& Burda R. (2000). Ecoflora of Ukraine. 1. Kyiv: Fitosotsiosentr.

Didukh, Ya.P., Mala, J.I., Pashkevich, N.A., Fitsailo, T.V. \& Khodosovtsev O.E. (2016). Biotopes of the Crimean Mountains. Kyiv: Interservis.

Lambdon, P.W., Pyšek, P., Basnou, C., Hejda, M., Arianoutsou, M., Essl, F., Jarošík, V., Pergl, J., Winter, M., Anastasiu, P., Andriopoulos, P., Bazos, I., Brundu, G., Celesti-Grapow, L., Chassot, P., Delipetrou, P., Josefsson, M., Kark, S., Klotz, S., Kokkoris, Y., Kühn, I., Marchante, H., Perglová, I., Pino, J., Vila, M., Zikos, A., Roy, D. \& Hulme P.E. (2008). Alien flora of Europe: Species diversity, temporal trends, geographical patterns and research needs. Preslia, 80, 101-149.

McNeely, J.A., Mooney, H.A., Neville, L.E., Schei, P.J. \& Waage J.K. (Eds.) (2001). Global strategy on invasive alien species. Switzerland and Cambridge: IUCN, Gland.

Mosyakin, S.L. \& Fedoronchuk M.M. (1999). Vascular plants of Ukraine: A nomenclatural checklist. Kiev: M.G. Kholodny Institute of Botany, Missouri Botanic Gardens.

Mosyakin, S.L. (2013). Rodyny i porjadky kvitkovyh roslyn flory Ukrainy: pragmatychna klasyfikaciia ta polozhennia u philogenetychnyi systemi. Ukrainian Botanical Journal, 70(3), 289-307. DOI: 10.15407/ukrbotj70.03.289.

Richardson, D.M., Pyšek, P., Rejmanek, P.M., Barbour, M.G., Panetta, F.D. \& West C.J. (2000). Naturalization and invasion of alien plants: Conception and definitions. Divers. Distrib., 6, 93-107. DOI: 10.1046/j.14724642.2000.00083.x.

The International Plant Name Index (IPNI). Retrieved from http://www.ipni.org/index.html.

The Plant List. A working list of all plant species. Retrieved from http://www.theplantlist.org. 